\title{
Phaeosphaeria deschampsii (Ascomycota): A new parasite species of Deschampsia antarctica (Poaceae) described to Antarctica
}

\author{
JAIR PUTZKE ${ }^{1}$ and ANTONIO B. PEREIRA ${ }^{2}$ \\ ${ }^{1}$ Universidade de Santa Cruz do Sul/UNISC, Instituto Nacional de Ciência e Tecnologia Antártico de Pesquisas \\ Ambientais/INCT-APA, Av. Independência, 2293, 96815-900 Santa Cruz do Sul, RS, Brasil \\ ${ }^{2}$ Universidade Federal do Pampa/UNIPAMPA, Instituto Nacional de Ciência e Tecnologia Antártico de \\ Pesquisas Ambientais/INCT-APA, Av. Antonio Trilha, 1847, 97300-000 São Gabriel, RS, Brasil
}

Manuscript received on November 11, 2015; accepted for publication on April 18, 2016

\begin{abstract}
This study presents the description of Phaeosphaeria deschampsii, which was found in plant communities from Half Moon Island, South Shetland Archipelago, Antarctica, in February 2014. Many patches of Deschampsia antarctica (Poaceae), the only indigenous Poaceae specie in Antarctic, were found dead, parasitized by a fungi pathogen. Based on the shape of its perithecia, with oblique neck, erumpent in the grass tissues, ascospore form and septation, the specie was identified as new to science.
\end{abstract}

Key words: Antarctica, Ascomycota, grass, phytopathology.

\section{INTRODUCTION}

Plant pathogens are little known from the Antarctic region, generally reported from lichens and mosses more than from angiosperms. The fanerogams are restricted to only two species in this continent: Colobanthus quitensis Kunth (Caryophyllaceae) and Deschampsia antarctica Desv. (Poaceae) (Putzke and Pereira 1996). World climatic change is occurring and pathogens usually restricted to some areas are now being found in new sites as saprophytes or sometimes as pathogens.

Phaeosphaeria is a fungus genus restricted as parasitic of Poaceae and some other grass-like

Correspondence to: Antonio Batista Pereira

E-mail: anbatistape@gmail.com monocot plants. Some species are very specialized while others have a large host spectrum (Stchigel et al. 2004).

During field work done in the Antarctic (Half Moon Island), we collected many samples of dead D. antarctica presenting well-developed symptoms that is the fungi peritecia present on the plant lives. The pathogen was compared to all known taxa from Antarctica (Pegler et al. 1980) and all around the world and was found as a new species to science.

The main purpose of this work is to describe this pathogen, contributing with the knowledge of pathogens distribution and their impact over native plant communities in Antarctica.

The MycoBank is deposit this one new taxon: (MB 817663). 


\section{MATERIALS AND METHODS}

Halfmoon Island $\left(62^{\circ} 36^{\prime} \mathrm{S}, 59^{\circ} 53^{\prime} \mathrm{W}\right)$ is located between Livingston and Greenwich Islands, in the South Shetland Archipelago. The small island is about $3 \mathrm{~km}$ long and its name is derived from its halfmoon-like contour, whose concavity opens toward the north-west.

The $D$. antarctica small cespitose especimes found in this island were revised for symptoms of diseases and all the suspected material was carried to the laboratory settled at the Camara Base (Argentine). The samples were examined in stereoscopic microscope and lots of perithecia were found. Cuts were done and slides were prepared for microscopic observation. Photographs were taken (Camera Canon EOS 550) directly from an Olympus microscope.

\section{RESULTS}

The samples collected were found parasitized by a Phaeosphaeria deschampsii J. Putzke \& A.B. Pereira fungus, which is considered new to science. The description is presented below:

Phaeosphaeria deschampsii J. Putzke \& A.B. Pereira sp. nov.

MycoBank - (MB 817663).

Ascoma as isolated erumpent perithecia, very numerous per leaf, 250 x $500 \mu \mathrm{m}$ diam., having oblique neck, with lose hyphae occurring on the outer wall. Neck $40-50$ x $70-80 \mu \mathrm{m}$. Wall formed by brownish polygonal cells $5-7$ x $5-7$ $\mu \mathrm{m}$; ostiolum 25 - $45 \mu \mathrm{m}$ diam., without periphysis. Cylindrical paraphyses. Cylindric asci, $100-120 \mathrm{x}$ 10-14 $\mu \mathrm{m}, 8$-spored. Biseriate ascospore, fusiform, straight or somewhat curved, $25-30 \times 6-7 \mu \mathrm{m}$, 8 -septate, hyaline when young and yellowishbrown when mature, first septa sub-medial, constricted, eguttulate, smooth and without mucous sheath (Figure 1).

Our collection was found occurring on D. antarctica, killing branches among healthy

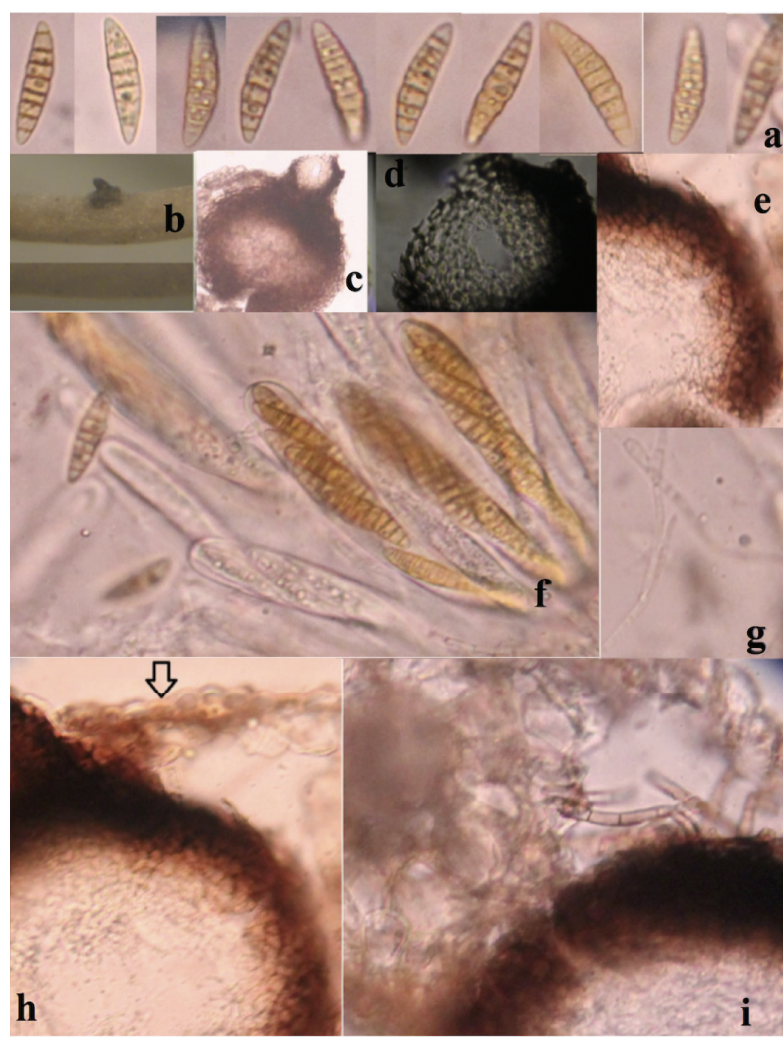

Figure 1 - $P$. deschampsii: a- ascospores; b- perithecia; clongitudinal section of perithecia; $\mathbf{d}$ - cross section of perithecial neck; e- perithecial wall; $\mathbf{f}$ - some mature asci together with some young ones; g- paraphyses; h- perithecial wall and epidermial cells of the host (setae); i- loosely disposed hyphae in the perithecia outerwall.

plants (Figure 2) or resulting in dead of all plant including fertile ones, reducing seed production. Some patches were completely dead, showing a whitish color, with all parts of the plant presenting perithecia.

Material examined: Antarctica, Half Moon Island, at southwest elevations near Camara Base, J. Putzke, HCB (18077- (HOLOTYPE).

\section{DISCUSSION}

Phaeosphaeria mounceae Shoemaker and Babcock is the closest one in this genus, but the erumpent obliquely necked perithecia and ascospores with 8 septa differentiated it very well (Shoemaker and Babcock 1988). 


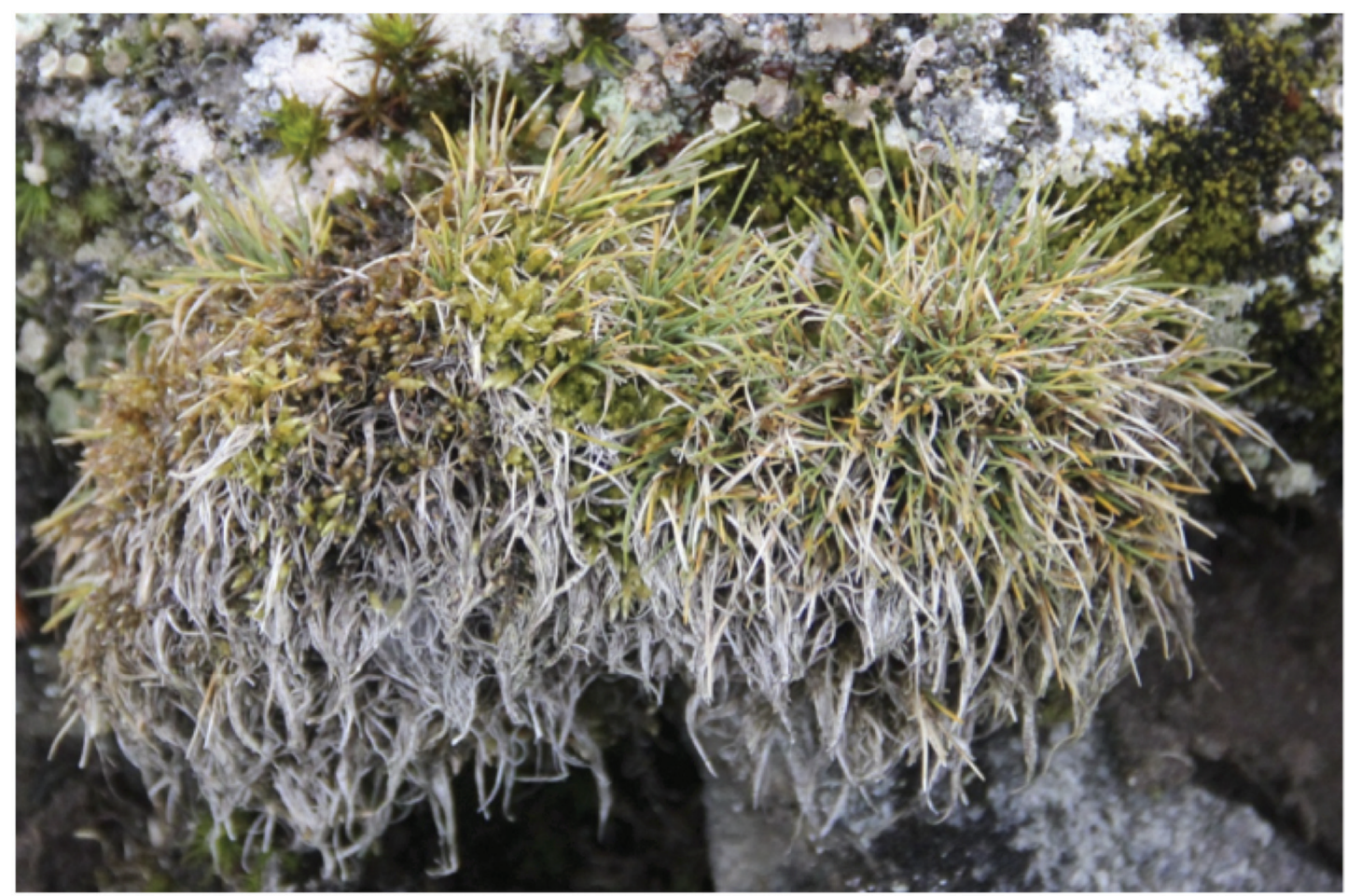

Figure 2 - Symptoms of $P$. deschampsii on $D$. antarctica leaves.

Phaeosphaeria microscopica (Karsten) O. Erikss. was reported by (Stchigel et al. 2004) to Antarctica, a widespread species, which differs specially by ascospore septae number (only 3 septa).

\section{ACKNOWLEDGMENTS}

This work was supported by the Brazilian Antarctic Program through Conselho Nacional de Desenvolvimento Científico e Tecnológico (CNPq) (process no. 574018/2008), Fundação Carlos Chagas Filho de Amparo à Pesquisa do Estado do Rio de Janeiro (FAPERJ) (process no. E-26/170.023/2008) Ministério da Ciência, Tecnologia e Inovação (MCTI), Ministério do Meio Ambiente (MMA) and CIRM, through INCT-APA.

\section{RESUMO}

Este estudo apresenta a descrição de Phaeosphaeria deschampsii, a qual foi encontrada em comunidades de plantas da Ilha Half Moon, Arquipélago das Shetland do Sul, Antártica, em fevereiro de 2014. Muitos céspedes de Deschampsia antarctica (Poaceae), a única espécie de Poaceae indígena na Antártica, foram encontrados mortos, parasitados por um fungo patógeno. Baseado no formato do peritécio, com pescoço oblíquo, erumpente dos tecidos da grama, forma dos ascósporos e septacão, a espécie foi identificada como nova para a ciência.

Palavras-chave: Antártica, Ascomycota, grama, fitopatologia.

\section{REFERENCES}

PEGLER DN, SPOONER BM AND LEWIS SMITH RI. 1980. Higher fungi of Antarctica, the Subantarctic zone and the Falkland Islands. Kew Bull 35: 499-562.

PUTZKE J AND PEREIRA AB. 1996. Macroscopic fungi the South Shetlands, Antarctica. Ser Cientif INACH 46: 31 39.

SHOEMAKER RA AND BABCOCK CE. 1988. Phaeosphaeria. Can J Bot 67: 1500-1599.

StChigel AM, CALduch M, MAC CORMACK W AND GUARro J. 2004. Phaeosphaeria microscopica (Karsten) O. Erikss.: first report on Deschampsia antarctica Desv. Bol Micol 19: 111-115. 